\title{
Response of Barley (Hordium vulgare L.) to Integrated Cattle Manureand Mineral Fertilizer Application in the Vertisol Areas of South Tigray, Ethiopia
}

\author{
Assefa Workineh Chekole \\ Tigray agricultural research institute, Alamata agricultural research center, Alamata, Ethiopia
}

Email address:

assefaw.02@gmail.com

To cite this article:

Assefa Workineh Chekole. Response of Barley (Hordium vulgare L.) to Integrated Cattle Manureand Mineral Fertilizer Application in the Vertisol Areas of South Tigray, Ethiopia. Journal of Plant Sciences. Vol. 3, No. 2, 2015, pp. 71-76. doi: 10.11648/j.jps.20150302.15

\begin{abstract}
A study to investigate the effect of integrated mineral and cattle manure fertilizers on grain yield of Barley (Hordium Vulgar L.) was evaluated during 2013 and 2014 main cropping season on vertisols of southern Tigray Ethiopia. The treatment consists four level of $\mathrm{N} / \mathrm{P}_{2} 0_{5}$ fertilizer combination $\left(0 / 0,23 / 23,46 / 46,69 / 69 \mathrm{~kg} \mathrm{ha}^{-1}\right)$ and five levels of farm yard manure $(0,4$, 6,8,10 ton $\mathrm{ha}^{-1}$ ) and their interactions arranged in Randomized Complete Block Design (RCBD) in three replication. The combined statistical analysis over locations revealed significant main effects of FYM and NP fertilizers $(p \leq 0.05)$ and interactions effects on grain yield of barley. There were also highly significance variation among N/P fertilizer main effect for biomass, physiological maturity, plant height, seeds per spike and effective tiller per plant, however no significance variation between the FYM main effects and interaction effects of NP and FYM for biomass, physiological maturity, plant height seeds per spike and effective tiller per plant. Grain yield consistently respond to increasing level of fertilizations in the form of NP, FYM or their integration. The results of this finding showed that combined application of $69 / 69 \mathrm{~N} / \mathrm{P}_{2} 0_{5} \mathrm{~kg} \mathrm{ha}^{-1}+10$ ton ha ${ }^{-1}$ FYM, 69/69 N/P $\mathrm{P}_{2} 0_{5} \mathrm{~kg} \mathrm{ha}^{-1}+8$ ton $\mathrm{ha}^{-1} \mathrm{FYM}$ and $69 / 69 \mathrm{~N} / \mathrm{P}_{2} 0_{5} \mathrm{~kg}$ ha-1 +6 ton $\mathrm{ha}^{-1} \mathrm{FYM}$ significantly $(\mathrm{P}<0.05)$ increase the yield of barley than other treatments. Integrated application of 46/46 N/P205 kg ha-1 with $8 \mathrm{t} \mathrm{ha}^{-1}$ gave $18 \%$ and $100 \%$ yield increment than current (46/46 N/P2 $05 \mathrm{~kg} \mathrm{ha}^{-1}$ ) blanket fertilizer recommendation in the area and the control. This may greatly benefits farmers in area where supply of mineral fertilizer is low or cases where farmers can't afford the cost of high fertilizer input. Higher grain yield (2.9 ton $\mathrm{ha}^{-1}$ ) was obtained from residual effects of 8 ton ha ${ }^{-1} \mathrm{FYM}$ applied in 2013 on barley grain yields in 2014 cropping season received $46 / 46 \mathrm{~kg} \mathrm{ha}^{-1} \mathrm{~N} / \mathrm{P}_{2} 0_{5}$.
\end{abstract}

Keywords: Farmyard Manure, NP Fertilizers, Barley

\section{Introduction}

Barley (Hordeum vulgare) is one of the most important cereal crop, mainly grown by smallholder farmers at midand high altitudes Ethiopia, predominantly between 2200 $3000 \mathrm{~m}$ a.s.l [1]. It is one of the most important small cereal crops, which ranks fourth after wheat, maize and rice in the world [2] and $5^{\text {th }}$ in Ethiopia both in terms of area and production after Teff, Maize, Sorghum and Wheat [3]. Food barley is commonly cultivated in stressed areas where soil erosion, occasional drought or frost limits the ability to grow other crops [4].

Low soil fertility has been recognized as one of the major biophysical constraints affecting agriculture in sub-Saharan Africa[5]. Soils in the highlands of Ethiopia exhibit low levels of essential plant nutrients and organic matter content
[6 and 7]. This is largely consequence of the cerealdominated cropping history of most fields and continuous nutrient mining by crop removal [8 and 9], which eventually leads to depletion of soil nutrients [6 and 10]. Soil nutrient depletion has been exacerbated by low levels of chemical fertilizer usage [6] due to both high cost and constraints to timely availability of the fertilizer input [11].

The poor soil fertility in northern Ethiopia has been blamed for limiting the production and production stability of barley [12] and nitrogen and phosphorus are among the most productivity limiting nutrients [13]. In southern Tigray ,the current fertilizer blanket recommendation is $46 / 46 \mathrm{~N} / \mathrm{P}_{2} 0_{5}$ $\mathrm{kgha}^{-1}$ and is used by some farmers, but most of the resource poor farmers are using even below the recommendation due to increasing fertilize cost. Even if there is huge number of livestock in the study area the culture of using farm yard 
manure as fertilizer source is not practiced well and the rate of application and incubation method is not scientifically recommended. So reducing the amount of mineral nitrogen fertilizers applied to the field without a nitrogen deficiency is the main challenge in field management. Therefore, to maintain soil fertility and productivity, the use of other alternative option of soil fertility replenishment is indispensable. Farmyard manure (FYM) is one potential source of nutrients as a result of the high cattle production of the region where on average there are 14 livestock per family [14].

Application of organic materials alone or in combination with inorganic fertilizer helped in proper nutrition and maintenance of soil fertility [15].According to reference no [16] reported that organic manures increased the efficiency of chemical fertilizers. Beneficial effects of farm yard manure on crop production through improved fertility and physical properties of soil are an established fact [17] and providing greater stability in production, but also maintaining better soil fertility status [18]. The long term effects of the combined application of organic and inorganic fertilizers in improving soil fertility and crop yield have been demonstrated by many workers [19]. In reference no [20] reported that organic and inorganic fertilizers showed great benefits not only for the increase in the $\mathrm{N}$ uptake by the plant but also in the improvement of the fodder yield. Research efforts on how to use this resource and use of FYM together with low rates of mineral fertilizers could be one alternative solution for sustainable fertility management and alleviate food self sufficiency specially for resource poor farmers. More over there is no research recommendation on NP, FYM, FYM and NP integration in the study. Therefore the study is initiated to evaluate the effect of different integrated mineral fertilizer and FYM application rate grain yield of barley.

\section{Material and Method}

\subsection{The Study Area}

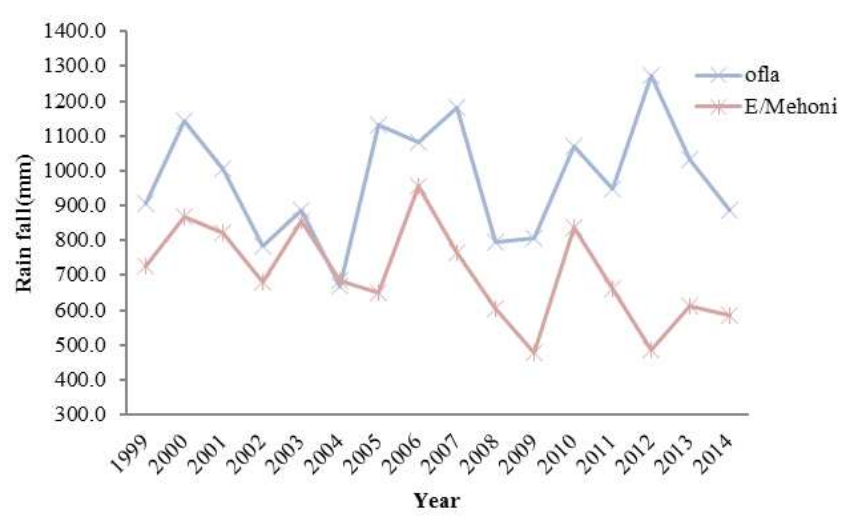

Figure 1. Sixteen year annual rain fall pattern of ofla and E/Mehoni districts

The study was conducted in ofla and Enda Mehoni districts of Southern zone of Tigray regional state, Ethiopia in 2013 and 2014 main cropping season. The livestock population in this zone consists of 699559 cattle, 269098 sheep, 398503 goats, 950 horses, 160761 donkeys, 2154 mule, 130303 camel, 845548 poultry and 52699 beehives [14]. Mixed livestock farming system is an agricultural production system practice in the area and livestock production is a major component of the livelihood system and provides draught power, food and income. Small ruminant production is one the component of the livestock production system. The rain fall pattern of the districts is presented in figure 1. The dominant soil type for the study area is vertisols with minimum and maximum air temperature of 8 and $220_{\mathrm{c}}$ respectively.

\subsection{Treatments and Experimental Design}

The FYM used for the experiment was well decomposed for three months under shade and applied all at planting with phosphorus fertilizer while $\mathrm{N}$ fertilizer was applied in split form with $1 / 3$ rd of the dose applied at planting and the remaining $2 / 3 \mathrm{rd}$ at tillering (40 days after sowing) stage of the crop. The source of phosphorus fertilizer was triple supper phosphate (TSP). Treatments were laid out in a randomized complete block design with three replications. The plot size was $3 \mathrm{~m} \times 2.4 \mathrm{~m}$ with $1.5 \mathrm{~m}$ between replication and $1 \mathrm{~m}$ between plot alleys. The treatments consists four level of N/P205 combination $\left(0 / 0,23 / 23,46 / 46,69 / 69 \mathrm{kgha}^{-1}\right)$ and five levels of farm yard manure levels $(0,4,6,8,10$ ton $\mathrm{ha}^{-1}$ ) and their interactions. The variety used in the experiment was Shedho.

\subsection{Data Collected}

\subsubsection{Soil Data Collection and Analysis}

Table 1. some socio physical properties of the study sites

\begin{tabular}{lll}
\hline Soil properties & Ofla & E/Mehoni \\
\hline PH & 6.3 & 7.3 \\
Total N (\%) & 0.0914 & 0.08 \\
Available P.(ppm) & 3.1 & 7.5 \\
OC (\%) & 0.675 & 0.98 \\
EC & 0.12 & 0.13 \\
CEC(Meq/100kg soil) & 46 & 44 \\
Ca(meq of ca/litter) & 11.1 & 9 \\
Mg(meq of ca/litter) & 5 & 5.1 \\
Clay (\%) & 60 & 44 \\
Sand (\%) & 15 & 31 \\
Silt (\%) & 25 & 25 \\
Textural class (USDA) & clay & clay \\
\hline
\end{tabular}

Composite soil samples were collect from the plow layers $(0-30 \mathrm{~cm})$ at each experimental site before applications of the treatments. A standard laboratory procedure for each parameter was followed in analyzing the composite surface soil samples. The results of the laboratory analysis of some physico-chemical properties of the soil used for the experiment are presented in Table 1. Accordingly, Soil samples were analyzed for texture, organic carbon, total nitrogen, Cation Exchange Capacity (CEC), available P, exchangeable $\mathrm{Ca}$ and $\mathrm{Mg}, \mathrm{PH}$, total nitrogen and available phosphorus. The methods used for physico-chemical analysis 
were: Organic matter content was determined by oxidation of organic carbon with acid potassium di-chromate (K2Cr2O7) by the Walkley and Black method [21]. Total nitrogen was analyzed by Micro-Kjeldhal method [22]. Soil pH was determined in 1:2.5 (weight/ volume) soil to water dilution ratio [21]. Cation exchange capacity was measured after saturating the soil with $1 \mathrm{~N}$ ammonium acetate (NH4OAC) and displacing it with $1 \mathrm{~N} \mathrm{NaOAC} \mathrm{[23].} \mathrm{Available} \mathrm{phosphorus}$ was determined using Olsen method [24].

\subsubsection{Agronomic Data}

- Days to maturity (DM): Physiological maturity was calculated by counting the number of days from $50 \%$ emergence to the stage when $90 \%$ of the plant reaches physiological maturity.

- Plant height $(\mathrm{cm})$ : Plant height was measured from ten sampled plants from the base of the main stem to the upper tip of the plants, using measuring tape. Total height was divided with the number of sampled plants to get average plant height.

- Biomass yield (kg plot $\left.{ }^{-1}\right)$ : Total above ground biological yield was weighted from each plot, excluding the two boarder rows after well sun-drying. Then yield per plot was converted into hectare basis.

- Effective tiller number (ETN): Effective tiller number was determined from randomly selected area of $0.25 \mathrm{~m}^{2}$ $(0.5 \times 0.5 \mathrm{~m})$ by counting the number of plants after emergence and number of plants bearing fertile spike at maturity and considering their difference as effective number. Total number of fertile spike was divided with the number of sample plants to get fertile spikes on plant basis.

- Spike length $(\mathrm{cm})$ : Spike length was determined in cent meter from ten randomly selected plants in each plot. Total height was divided with the number of sampled plants to get average height per spike.
- Number of grains per spike (SPS $\left.{ }^{-}\right)$: Grains per spike were counted from ten randomly selected spikes of each plot, and the total grains number was divided by the sampled plants to get average number of grains per spike.

- Grain yield $\left(\mathrm{kg} \mathrm{plot}^{-1}\right)$ : The grain yield was taken from each plot by excluding the border rows and adjusted to $12.5 \%$ moisture level and then converted to hectare basis.

\subsection{Data Analysis}

The Analysis of Variance (ANOVA) on the relevant responsive variable was computed using the GLM procedure of SAS version 9.2 [25] following the standard procedures of ANOVA for RCB design [26]. The differences among locations and among treatments were considered significant if the P-values were $\leq 0.05$. Least Significance Difference (LSD) was used to compare among varieties at 5\% probability level.

\section{Result and Discussion}

Laboratory analytical results of selected physicochemical properties of the soil on which these on-farm experiments were conducted is presented in Tables 2. Soils in the study areas are dominantly clay in texture and vary from slightly acidic to neutral. The soil organic and total Nitrogen contents at all locations are very low and total indicating the low fertility status of the soils aggravated by continuous cultivation, and lack of incorporation of organic materials into the soils. The cation exchange capacity (CEC) of the experimental site was 44 and $46 \mathrm{Meq} / 100 \mathrm{~kg}$ soil for ofla and Enda Mehoni respectively. The available phosphorus was also below critical.

Table 2. Main effect of farm yard manure and NP fertilizer application on different trait of Barley at ofla and E/Mehoni areas in 2013 cropping season

\begin{tabular}{|c|c|c|c|c|c|c|c|}
\hline $\mathrm{N} / \mathrm{P}_{2} \mathbf{0}_{5}\left(\mathrm{~kg} \mathrm{ha}^{-1}\right)$ & GY(t ha $\left.{ }^{-1}\right)$ & DM & PH(cm) & $\mathrm{SL}(\mathrm{cm})$ & ETN & SPS & BY $\left(\mathrm{t} \mathrm{ha}^{-1}\right)$ \\
\hline $0 / 0$ & 2.119 & 101.7 & 83.65 & 3.99 & 3.03 & 23.81 & 3.29 \\
\hline $23 / 23$ & 2.585 & 100.1 & 91.25 & 4.48 & 3.82 & 24.25 & 4.07 \\
\hline $46 / 46$ & 3.016 & 96.63 & 95.60 & 4.66 & 3.76 & 27.9 & 4.73 \\
\hline $69 / 69$ & 3.662 & 99.13 & 98.81 & 4.85 & 4.45 & 29.77 & 4.95 \\
\hline LSD & 0.25 & 1.87 & 5 & 0.29 & 0.41 & 2.89 & 0.589 \\
\hline \multicolumn{8}{|l|}{ FYM $\left(\right.$ tha $\left.^{-1}\right)$} \\
\hline 0 & 2.437 & 100.75 & 89.89 & 4.504 & 4.10 & 26. & 3.47 \\
\hline 4 & 2.784 & 98.96 & 90.90 & 4.550 & 4.19 & 26 & 4.13 \\
\hline 6 & 2.764 & 100.96 & 92.02 & 4.571 & 4.00 & 28. & 4.32 \\
\hline 8 & 3.191 & 100.42 & 95.06 & 4.500 & 4.19 & 27. & 4.73 \\
\hline 10 & 3.052 & 99.62 & 93.84 & 4.350 & 4.23 & 25. & 4.64 \\
\hline LSD & 0.41 & $\mathrm{~ns}$ & ns & $\mathrm{ns}$ & $\mathrm{ns}$ & ns & 0.654 \\
\hline
\end{tabular}

Where; $\mathrm{DH}=$ days to heading, $\mathrm{DM}=$ Days to maturity, $\mathrm{PH}=\mathrm{Plant}$ height, $\mathrm{BY}=$ Biomass yield, ETN $=$ Effective Tillers per plant, $\mathrm{GY}=\mathrm{Grain}$ yield, $\mathrm{SL}=\mathrm{Spike}$ length and SPS=Number of seed per spike

The combined statistical analysis over locations revealed significant $(p \leq 0.05)$ main effects of FYM, NP fertilizers and interactions effects on grain yield of barley. There were also highly significance variation among N/P fertilizer main effect for biomass, physiological maturity, plant height, seeds per spike and effective tiller per plant, however no significance variation between the FYM main effects and interaction effects of NP and FYM for biomass, physiological maturity, 
plant height seeds per spike and effective tiller per plant. Grain yield consistently respond to increasing level of fertilizations in the form of NP, FYM or their integration. Significantly more grain yields were obtained in treatments receiving combined application of $69 / 69 \mathrm{~kg} \mathrm{ha}^{-1} \mathrm{~N} / \mathrm{P} 205$ with $10 \mathrm{t} \mathrm{ha}^{-1}$ of manure and followed $69 / 69 \mathrm{~kg} \mathrm{ha}^{-1} \mathrm{~N} / \mathrm{P} 205$ with 8 $\mathrm{t} \mathrm{ha}^{-1}$ and $69 / 69 \mathrm{~kg} \mathrm{ha}^{-1} \mathrm{~N} / \mathrm{P} 205$ with $6 \mathrm{t} \mathrm{ha}^{-1}$ respectively. Up to $18 \%$ and $100 \%$ grain yield increment was also recorded in integrated application of 46/46 N/P205 kg ha ${ }^{-1}+6$ tha $^{-1}$ FYM than the present N/P205 fertilizer recommendation and control treatment respectively.
This study, there for strongly confirms the role of manure and chemical fertilizer in increasing grain yield of barley but a combination of them has more effect on increasing in grain yield. Integrated soil fertility management involving the judicious use of combinations of organic and inorganic resources is a feasible approach too overcomes soil fertility constraints 27, 28 and 29] and contribute high crop productivity in agriculture [30]. In reference no [31, 32 and 33] reported also similar observations of getting higher yields of Barley grain with combined application of FYM and inorganic fertilizers.

Table 3. Interaction effect of farm yard manure and NP fertilizer application on different trait of barley at ofla and E/Mehoni areas in 2013 cropping season

\begin{tabular}{|c|c|c|c|c|c|c|c|c|}
\hline $\mathrm{N} / \mathbf{P}_{2} \mathbf{0}_{5}\left(\mathrm{~kg} \mathrm{ha}^{-1}\right)$ & FYM(t ha $\left.{ }^{-1}\right)$ & GY(t ha $\left.{ }^{-1}\right)$ & DM & PH(cm) & SL(cm) & ETN & SPS & BY $\left(\mathrm{t} \mathrm{ha}^{-1}\right)$ \\
\hline $0 / 0$ & 0 & 1.6 & 101.2 & 78.1 & 4.1 & 2.8 & 22.0 & 2.5 \\
\hline $0 / 0$ & 4 & 2.1 & 101.3 & 78.1 & 4.2 & 2.8 & 23.4 & 3.0 \\
\hline $0 / 0$ & 6 & 2.0 & 102.2 & 86.5 & 4.0 & 3.3 & 26.3 & 3.4 \\
\hline $0 / 0$ & 8 & 2.5 & 101.7 & 90.0 & 4.0 & 3.4 & 27.4 & 4.3 \\
\hline $0 / 0$ & 10 & 2.4 & 102.2 & 85.6 & 3.7 & 2.9 & 19.9 & 3.3 \\
\hline $23 / 23$ & 0 & 2.2 & 101.5 & 84.6 & 4.5 & 3.6 & 24.4 & 3.1 \\
\hline $23 / 23$ & 4 & 2.8 & 99.3 & 92.2 & 4.6 & 4.1 & 23.2 & 4.1 \\
\hline $23 / 23$ & 6 & 2.4 & 101.5 & 88.6 & 4.5 & 4.0 & 24.7 & 4.4 \\
\hline $23 / 23$ & 8 & 2.9 & 99.5 & 96.4 & 4.5 & 3.8 & 21.8 & 4.2 \\
\hline $23 / 23$ & 10 & 2.6 & 98.7 & 94.4 & 4.4 & 3.7 & 27.3 & 4.5 \\
\hline $46 / 46$ & 0 & 2.8 & 100.8 & 96.1 & 4.7 & 4.0 & 27.6 & 4.7 \\
\hline $46 / 46$ & 4 & 3.0 & 98.5 & 98.4 & 4.6 & 3.3 & 24.1 & 4.7 \\
\hline $46 / 46$ & 6 & 2.8 & 100.2 & 95.1 & 5.0 & 3.5 & 28.3 & 4.0 \\
\hline $46 / 46$ & 8 & 3.3 & 100.3 & 97.0 & 4.5 & 4.1 & 33.5 & 5.1 \\
\hline $46 / 46$ & 10 & 3.1 & 98.3 & 91.8 & 4.6 & 3.8 & 26.0 & 5.1 \\
\hline $69 / 69$ & 0 & 3.1 & 99.5 & 100.8 & 4.8 & 4.1 & 30.6 & 3.5 \\
\hline $69 / 69$ & 4 & 3.2 & 96.7 & 94.9 & 4.9 & 3.8 & 34.2 & 4.7 \\
\hline $69 / 69$ & 6 & 3.8 & 100.0 & 97.9 & 4.9 & 5.0 & 31.9 & 5.5 \\
\hline $69 / 69$ & 8 & 4.0 & 100.2 & 97.0 & 4.9 & 4.8 & 25.9 & 5.3 \\
\hline $69 / 69$ & 10 & 4.1 & 99.3 & 103.5 & 4.8 & 4.6 & 26.2 & 5.7 \\
\hline LSD & & 0.469 & $\mathrm{~ns}$ & ns & ns & ns & 6.5 & ns \\
\hline CV $(\%)$ & & 17.3 & 3.6 & 10.57 & 12.5 & 20.76 & 21.27 & 26.7 \\
\hline
\end{tabular}

Where; $\mathrm{DH}=$ days to heading, $\mathrm{DM}=$ Days to maturity, $\mathrm{PH}=\mathrm{Plant}$ height, $\mathrm{BY}=\mathrm{Biomass}$ yield, TPP= Tillers per plant, GY=grain yield, $\mathrm{SL}=\mathrm{Spike}$ length, $\mathrm{SPS}=$ Number of seed per spike and $\mathrm{ns}=$ no significance.

Table 4. Main effects of FYM and NP fertilizer residues applied in 2013 on barley grain yield in 2014

\begin{tabular}{ll}
\hline $\mathbf{N} / \mathbf{P}_{\mathbf{2}} \mathbf{0}_{\mathbf{5}}(\mathbf{k g}$ ha-1) & GY (t ha-1) \\
\hline $0 / 0$ & 1.720 \\
$23 / 23$ & 2.393 \\
$46 / 46$ & 2.393 \\
$69 / 69$ & 2.393 \\
\hline $\mathrm{LSD}(0.5)$ & 0.137 \\
\hline FYM (t ha-1) & \\
0 & 2.164 \\
4 & 2.121 \\
6 & 2.353 \\
8 & 2.563 \\
10 & 2.363 \\
$\mathrm{LSD}(0.5)$ & 0.153 \\
$\mathrm{CV} \%$ & 8.0 \\
\hline
\end{tabular}

Significantly more grain yield was also obtained at 2014 from residual of farm yard manure in applied 2013 (Table4); this may due to the slow release of nutrients from FYM in the former cropping season. Mineral fertilizers in improving crop yields [34, 35 and 36]. Additional 0.4 ton per hectare of barley grain yield was obtained from residual interaction effect of $46 / 46 \mathrm{~kg}$ ha- $1 \mathrm{~N} / \mathrm{P}_{2} 0_{5}+8 \mathrm{t} \mathrm{ha}^{-1} \mathrm{FYM}$.
Manure fertilizer treatments had beneficial residual effects on crop production and use from manure fertilizer for field fertilization and production of crops was better improved. Significantly high grain was obtained from residual application of $8 \mathrm{t} \mathrm{ha}^{-1}$ and is proportional with existing fertilizer recommendation. Therefore for resource poor farmers combined application of farm yard manure and mineral fertilizer is very economical than sole NP application.

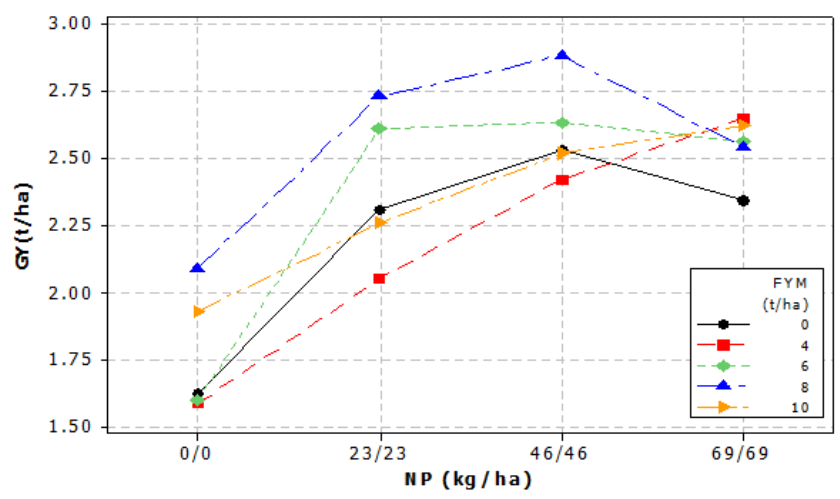

Figure 2.Residual effect of Farm yard manure on Grain of Barley 


\section{Conclusion}

From this finding the integrated use of farm yard manure, and $\mathrm{N}$ and $\mathrm{P}$ fertilizers are efficient than the use of either N/P or FYM alone. It can be concluded that use of farmyard manure and chemical fertilizer considerably improve grain yield of barley. The result in this investigation showed that use of $69 / 69 \mathrm{~kg} \mathrm{ha}^{-1} \mathrm{~N} / \mathrm{P}_{2} 0_{5}$ chemical fertilizer integrated with $6 \mathrm{t} \mathrm{ha}{ }^{-1}$ manure fertilizer could produce satisfactory yield of barley in the study area and farm yard manure treatments had beneficial residual effects on barley crop production.

\section{References}

[1] Asmare Yallew, Alemu Hailiye, Alemayehu Assefa, Melkamu Ayalew, Tessema Zewudu, Berihane Assayegn \& Halima Hassen. Barley production practices in Gojam and Gondar. In: Chilot Yirga, Fekadu Alemayehu \& Woldeyesus Sinebo (eds.). Barley based farming system inthe high lands of Ethiopia. Ethiopian AgriculturalResearch Organisation. Addis Ababa,Ethiopia. pp. 67-89. 1998.

[2] Onwueme, I.C. and T.D. Sinha. Field Crop Production in Tropical Africa. CTA. 1999.

[3] CSA (Central Statistic Authority)-Agricultural Sample Survey 2013/2014: Volume VII - Report on Area and Production Crops (Private Peasant Holdings, Meher Season), Statistical Bulletin 573, Central Statistical Agency (CSA), the Federal Democratic Republic of Ethiopia. 2014.

[4] Birhanu, B., Fekadu, A. \& Berhane, L. Food barley in Ethiopia. In: S. Grando and M. H. Gomez (Eds), Food barley: importance, uses and local knowledge. Proceedings of the International Workshop on Food Barley Improvement, 14-17 January 2002, Hammamet, Tunisia. Aleppo: ICARDA. Pp5381.2005.

[5] Sanchez, P.A., Shepherd K.D., Soule M.J., Place F.M., Buresh R.J., Izac A.M., Mokwunye A.U., Kwesiga F.R., Ndiritu C.N.,Woomer PL Soil fertility repl enishment in Africa: an investment in natural resource capital. In: Buresh at al. (Eds). Replenishing Soil Fertility in Africa. SSSA Special Publication No 51. Madison, Wisconsin, USA.1997.

[6] Asnakew Woldeab, Tekaling Mamo, Mengesha, Bekelle \& Teferra, Ajema. Soil fertility management studies on wheat in Ethiopia. pp 137-172, in: Hailu Geberemariam, D.G. Tanner and Mengistu Huluka (eds.). Wheat Research in Ethiopia. A Historical Perspective. CIMMYT/IAR, Addis Ababa, Ethiopia.1991.

[7] Tekalign M., Hanque I., Kamara G.S. phosphorus statuse of some Ethiopian high lnad $\mathrm{s}$ in proceeding of management of vertisolias in sub Saharan Africa. International livessock center for Africa. Adis Ababa Ethiopia.1998.

[8] Amsal Tarekegne, Hailu Gebre \& Francis, C.A. Yield limiting factors to food barley production in Ethiopia. Journal of Sustainable Agriculture, 10: 97-113.1997.

[9] Amanuel Gorfu, Asefa Taa, Tanner, D.G. and W. Mwangi. 1991. On-Farm Research To Derive Fertilizer Recommendations For Small-Scale Bread Wheat Production: Methodological Issues And Technical Results. Research Report No. 14. IAR, Addis Ababa, Ethiopia. 37 p.
[10] Tanner, D.G., Amanuel Gorfu and Asefa Taa. Fertiliser effects on sustainabiljty in the wheat-based smallholder farming systems of Ethiopia. Field Crops Resrearch 33: 235-248.1993.

[11] Gezahegn Ayele and Tekalign Mamo. Determinants of demand for fertilizer in a Vertisol cropping system in Ethiopia. Tropical Agriculture (Trinidad) 72: 165-169.1995.

[12] Fekadu, W \& Skjelvåg, A. Soil water requirements and response to fertilization of barley in Northern Ethiopia. Doctoral Scientiarum Thesis. Agricultural university of Norway.2002.

[13] Kho, R. Crop production and the balance of available resources. Agriculture, Ecosystem and Environment, 80: 7185.200 .

[14] CSA (Central Statistic Authority) -Agricultural Sample Survey 2010/2011: Volume I - Report on Area and Production Crops (Private Peasant Holdings, Meher Season), Statistical Bulletin 417, Central Statistical Agency (CSA), the Federal Democratic Republic of Ethiopia, Addis Ababa.2011.

[15] Salim, M. S., M. Mian, and Mahmoodul Hassan. Annual technical report of project improvement of soil productivity through biological mean. Pak. Agric. Res. Council, Islamabad.1998.

[16] Hussain, T., G. Jullani, and M. Z. Iqbal. Integrated use of organic and inorganic $\mathrm{N}$ fertilizer in rice-wheat cropping system. Pak. J. Soil Sci. 3:19-23.1998.

[17] Singh, K. and Sarivastore. Effect of organic manure in Soil fertility as shown by nutrient availability and crop yield response in Potato New Pro. Symp. on soil evaluation, New Delhi.1971.

[18] Nambiar, K.K. Soil health and organic matter: Changing scenario. Proc. Nat. ACAD. Sci. India Spl. pp 141-160.1997.

[19] Chen, L.Z, Xia Z.L., Au SJ. 1988. The integrated use of organic and chemical fertilizer in China. SFCAAS (Ed.). Proceedings of International Symposium on Balanced Fertilization. Chinese Agric. Press, pp. 390-396.CIMMYT, Addis Ababa, Ethiopia. Addis Ababa.

[20] Wang X.B., Cia D.X, Hang J.Z. Land application of organic and inorganic fertilizers for corn in dry land farming in a region of north China sustaining global farm. D.E Ston. R.I.I.I. Montar and G.C. Steinhardt (Eds.), pp. 419-422.2001.

[21] Jackson M.L. Soil Chemical Analysis. Prentice Hall Inc., Engle wood cliffs, New Jersey.1958.

[22] Bremner, J. M., and C. S. Mulvaney. Methods of soil analysis: in Chemical and microbiological properties, ASA Monograph number 9. pp. 595-624. 1982.

[23] Chapman H.D. Cation Exchange Capacity by Ammonium Saturation. In: Black C.A., Ensminger LE and FE Clark (Eds). Method of Soil Analysis. American Society of Agronomy. Madison Wisconsin, USA. 891-901. 19965.

[24] Olsen S.R., Cole C.W., Watanabe F.S. and L.A. Dean Estimation of Available Phosphorus in Soils by Extraction with Sodium Bicarbonate Circular 939, US. Department of Agriculture. Methods of Soil Analysis. Part 2. Chemical and Microbiological Properties, Madison Wisconsin. 1982.

[25] SAS Institute. SAS/STAT guide for personal computers. Version 9.0 ed. SAS Institute INC., Cary, NC, USA.2002. 
[26] Montgomery D.C. Design and analysis of experiment. $3^{\text {rd }}$ edition. John Wiley and Sons, New York. USA.1991.

[27] Abedi T., Alemzadeh A., Kazemeini S.A. Effect of organic and inorganic fertilizers on grain yield and protein banding pattern of wheat. Aust J Crop Sci 4: 384-389.2010.

[28] Kazemeini S.A., Hamzehzarghani H., Edalat M. The impact of nitrogen and organic matter on winter canola seed yield and yield components. Aust J Crop Sci 4: 335- 342.2010.

[29] Mugwe J., Mugendi D., Kungu J., Muna M-M. Maize yields response to application of organic and inorganic input under on-station and on-farm experiments in central Kenya. Exp Agric 45: 47-59.2009.

[30] Pan G., Zhou P., L Z, Pete S., Li L, Qiu D., Zhang X., Xu X., Shen S., Chen X. Combined inorganic/organic fertilization enhances $\mathrm{N}$ efficiency and increases rice productivity through organic carbon accumulation in a rice paddy from the Tai Lake region, China. Agric Ecosyst Environ 131: 274-280.2009.

[31] Dudhat, M. S., D. D. Malavia, R. K. Mathukia, and V. D. Khanpara. Effect of organic manures and chemical fertilizers on wheat and their residual effect on green grain. Gujarat Agric. Univ. Res. J. 22 (1):4-8.1996.
[32] Kumar, R., and C. M. Singh. Crop yields and economics under fertilizer resource constraints along with different FYM application in maize-wheat cropping sequence. J. Hill Res.10 (2):103-107.1997.

[33] Vyas, S. H., M. M. Modhwadia, and V. D. Khanpara. Integrated nutrient management in wheat. Gujarat Agric. Univ. Res. J. 23 (1):12-18.1997.

[34] Heluf Gebrekidan, Asfaw Belay, Yohannes Uloro and Eylachew Zewdie. Yield response of maize (Zea mays L.) to crop residue management on two major soil types of Alemaya, eastern Ethiopia: I. Effects of varying rates of applied and residual NP fertilizers; Nutrient Cycling Agro.; 54:65-71.1999.

[35] Wakene N., G., and D. K. Friesen. Integrated Use of Farmyard Manure and NP fertilizers for Maize on Farmers' Fields. Journal of Agriculture and Rural Development in the Tropics and Subtropics Volume 106, No. 2, 131-141.2005.

[36] Ahmad Ghanbari, Mahdi Babaeian, Yasser Esmaeilian, Abolfazl Tavassoli and Ahmad Asgharzade. The effect of cattle manure and chemical fertilizer on yield and yield component of barley (Hordeum vulgare). African Journal of Agricultural Research Vol. 7(3), pp.504-508.2012. 